\title{
Miranda
}

Revue pluridisciplinaire du monde anglophone /

Multidisciplinary peer-reviewed journal on the English-

speaking world

$6 \mid 2012$

Marking the Land in North America

\section{Derek Walcott, White Egrets}

\section{Eric Doumerc}

\section{(2) OpenEdition}

\section{Journals}

Electronic version

URL: http://journals.openedition.org/miranda/3037

DOI: 10.4000/miranda.3037

ISSN: 2108-6559

\section{Publisher}

Université Toulouse - Jean Jaurès

\section{Electronic reference}

Eric Doumerc, "Derek Walcott, White Egrets", Miranda [Online], 6 | 2012, Online since 28 June 2012 connection on 16 February 2021. URL: http://journals.openedition.org/miranda/3037 ; DOI: https:// doi.org/10.4000/miranda.3037

This text was automatically generated on 16 February 2021.

\section{(c) (1)}

Miranda is licensed under a Creative Commons Attribution-NonCommercial-NoDerivatives 4.0 International License. 


\title{
Derek Walcott, White Egrets
}

\author{
Eric Doumerc
}

\section{REFERENCES}

Derek Walcott, White Egrets (London : Faber and Faber, 2010), 89 p, ISBN

978-0-571-25473-6

1 White Egrets is Derek Walcott's fourteenth collection of poems and is composed of 54 poems of varying lengths which address a number of themes and issues which recur constantly in Walcott's poetry. It is a cosmopolitan collection with a broad thematic range, but a number of key Walcottian concerns crop up again and again like love, the demise of the British empire, the Caribbean landscape, Caribbean history and death. All these themes are held together or united by the overarching themes of memory and the creative process.

2 Walcott's abiding love for the Caribbean and for Saint Lucia, his home island, appears in poem $n^{\circ} 3$ which is a tribute to the dockers in Castries' harbour that he used to observe as a child. These stevedores are presented as larger-than-life characters who have to face terrible odds, and who work hard, live hard and drink a lot to finally "shrink into [their] nicknames" (5), but it is a life-affirming poem as at the end the dockers "would roar like a lorry reviving in the prime of [their] drink". This piece is actually reminiscent of Chapter 3 of Another Life (London: Jonathan Cape, 1973) in which the persona wrote about the street people of Castries, the beggars and derelicts who were his heroes: "they were the stars of my mythology" (Collected Poems [London: Faber and Faber, 1986], 164).

3 The luscious landscape of Saint Mucia is celebrated in poem $n^{\circ} 17$, which has biblical overtones and delights in naming the landscape:

When light fell on the bushes beyond Soufrière

It was orderly, it named what it fell-

hog plum and zaboca, dasheen, tannia and melon

and between the hills, the orange and vermilion

immortelles that marked the cocoa's boundaries. (50) 
The piece entitled "The Acacia Trees" addresses the issue of the damage done by the tourist industry in the West Indies. The poem falls into three sections. The first part is about the social and environmental costs of tourism and the voice we hear is that of the persona/poet. The second section is spoken in a creole voice and is clearly workingclass. The third section moves back to the poet's voice. Here Walcott uses various tones of voice convincingly to make a point about the tourist industry in the Caribbean today.

5 The legacy of the British empire remains a major concern in Walcott's poetry and is featured in this collection. Two pieces, "The Lost Empire" and "The Spectre of Empire", deal with the issues of guilt and reconciliation. In "The Lost Empire", the mood is celebratory as the poet finds beauty in his home island after the departure of the colonisers ("This place produces nothing but beauty" [38]) but there is no rancour, no animosity as "light simplifies us whatever our race or gifts" (38). The poems is composed of two sections. The first section is a meditation on the demise of the empire and the poet paints on a very broad canvas, with references to "Sind, Turkestan, Canwpore" (37). The second half of the poem focuses on Saint Lucia and again delights in naming the landscape ("bois-canot, lauriers-cannelles" [38]), and the flora. Walcott's painterly gaze appears clearly in this poem as the last line alludes to the artist's vision which turns a small detail into a work of art ("to see how its wings catch colour when a gull lifts" [38]).

6 In "The Spectre of Empire", the poet addresses the issues of guilt and of the legacy of empire for the descendants of the colonisers, that is, the poor whites. The lone "whitedrill figure" who wanders the streets, dodging the "insults hurled at him" and retreating like a crab is reminiscent of the "white parchment Creole" who failed to recognise Shabine in Walcott's "Schooner Flight" (Collected Poems, 350) and is clearly a symbol of guilt. The punning line "Peccavi, I have Sind" (41) masterfully conveys this idea with sharp irony.

7 But to Walcott the colonial legacy is part of the Caribbean, must be acknowledged and cannot be wished away. Poem $n^{\circ} 22$ makes it clear that to the poet reconciliation and forgiveness are important values:

My enemy is a serpent

as much as he is in a fresco, and he in all his

scales and venom and glittering head is

part of the island's beauty; he need not repent. (55)

The title-poem, "White Egrets", is a meditation on art, memory and the passing of time. The poem is shot-through with references to death, decay and old age ("into that peace ... at which I may arrive eventually" [7]). Death is now a distinct possibility for the poet, and all his friends are "dying". But the white egrets remind him that art and poetry will always be with us and that the poet must keep on working. The egrets emerge as a symbol of the creative process: "selection is what the egrets teach" (10). The poet derives his inspiration from the Caribbean environment, from Nature ("a language beyond speech" [10]) and "White Egrets" is reminiscent of such poems as "Tarpon" (The Castaway [London: Jonathan Cape, 1965]) in which the Caribbean fauna emerges as a key source of inspiration for the poet. The poem ends on an elegiac note with a tribute to the late Russian poet Joseph Brodsky whose life was dedicated to art and poetry.

9 The egrets recur throughout the collection as a motif for creativity, thus holding it together, as in the poem entitled "In the Village": 
Watch these egrets

stalk the lawn in a dishevelled troopn white banners

forlornly trailing their flags; they are the bleached regrets

of an old man's memoirs, their unwritten stanzas.

Pages gusting like wings on the lawn, wide open secrets. (47)

10

$$
\begin{aligned}
& \text { "secrets" masterfully bring together the themes of craft, creativity, memory, the } \\
& \text { passing of time, and nature. }
\end{aligned}
$$

Old age and the coming of death are also featured in poem n ${ }^{\circ} 23$ : "What? You're going to be Superman at seventy-seven?/ Got your weight down?" (56) and in "In the Village".

Travelling is another important theme in this collection and several poems are set in Italy, Amsterdam, Spain and the USA. Walcott's ambivalent relationship with America, which was already an important theme in The Fortunate Traveller (New York: Farrar, Strauss and Giroux, 1981), in "Pastoral" (43). The poem starts as a celebration of America's natural beauty, but moves to a more accusatory mode with lines about the colonising process. The importance of religion in the building of the American nation is clearly alluded to with the "white country spire" which "insists on heaven" (43). "A London Afternoon" finds the poet in London, but he cannot recognise the England he was taught about at school, the seat of the British empire ("the red of empire"). Today's England with its "pizza joints" and "betting shops" (45) is a far cry from the sonnets by Sir Thomas Wyatt and the Earl of Surrey he used to study at school.

White Egrets also contains elegies dedicated to the late Aimé Césaire ("Elegy") and the late John Hearne, two giants of Caribbean literature, as well as tributes to the Jamaican poet Lorna Goodison and to Barack Obama ("40 acres").

14

Overall this collection confirms Derek Walcott's status as one of the greatest Caribbean poets as well as his enduring commitment to the Caribbean as a place where reconciliation is possible and where the whole world is contained.

\section{INDEX}

Keywords: art, British empire, Caribbean, colonial legacy, creativity, history, landscape, nature, Saint Lucia

Mots-clés: art, Caraïbes, créativité, Empire britannique, héritage colonial, histoire, nature, paysage, Sainte Lucie 
AUTHORS

\section{ERIC DOUMERC}

Maître de conférences

Université Toulouse 2 - Le Mirail

doumerceric@neuf.fr 